The University of Maine

\title{
DigitalCommons@UMaine
}

Marine Sciences Faculty Scholarship

School of Marine Sciences

8-1-2009

\section{The Effects of Smolt Stocking Strategies on Migratory Path Selection of Adult Atlantic Salmon in the Penobscot River, Maine}

D. Gorsky

J. Trial

J. Zydlewski

James McCleave

University of Maine - Main, mccleave@maine.edu

Follow this and additional works at: https://digitalcommons.library.umaine.edu/sms_facpub

\section{Repository Citation}

Gorsky, D.; Trial, J.; Zydlewski, J.; and McCleave, James, "The Effects of Smolt Stocking Strategies on Migratory Path Selection of Adult Atlantic Salmon in the Penobscot River, Maine" (2009). Marine Sciences Faculty Scholarship. 131.

https://digitalcommons.library.umaine.edu/sms_facpub/131 


\title{
The Effects of Smolt Stocking Strategies on Migratory Path Selection of Adult Atlantic Salmon in the Penobscot River, Maine
}

\author{
DIMITRY GORSKY*1 \\ Ecology and Environmental Science, University of Maine, Orono, Maine 04469, USA; \\ and Maine Atlantic Salmon Commission, 650 State Street, Bangor, Maine 04401, USA \\ JOAN TRIAL \\ Maine Atlantic Salmon Commission, 650 State Street, Bangor, Maine 04401, USA \\ JOSEPH ZYDLEWSKI \\ Department of Wildlife Ecology, University of Maine, Orono, Maine 04469, USA \\ JAMES MCCLEAVE \\ School of Marine Sciences, University of Maine, Orono, Maine 04469, USA
}

\begin{abstract}
Understanding the homing behavior of Atlantic salmon Salmo salar is vital to the restoration program employed on the Penobscot River, Maine. To produce significant adult returns, managers currently stock hatchery-raised smolts in specific river sections, providing smolts the opportunity to imprint on chemical signals and enabling their return to productive spawning and rearing habitat as adults. In this study, we used observational evidence from passive integrated transponder telemetry to determine whether adults returning from smolt stockings behaved in a way that suggested strong homing to smolt stocking locations. Adults returning from smolt stocking locations located in or at the mouth of the Piscataquis River were more likely to be detected as entering the Piscataquis River than were adults returning from the upper Penobscot River smolt stocking locations. In general, returning adult Atlantic salmon that had been stocked near or in tributaries as smolts chose a path more quickly than those that had been stocked in more downstream or mainstem locations. These results suggest that Atlantic salmon smolts should be stocked at specific sites with superior habitat for spawning and juvenile survival to capitalize on the strong homing tendency in adults. This technique can also be utilized to allow for natural selection and the development of localized stocks.
\end{abstract}

The ability of anadromous salmon to return to a natal stream successfully is pivotal to their reproductive success and, hence, population productivity. The foremost benefit of salmon returning to natal streams is that it increases the odds of adults returning to habitats of recent productivity (McDowall 2001). Effective homing promotes the development of stocks that are adapted to the prevailing conditions within a certain tributary or rearing habitat within a river system. Adaptation to local habitats is in turn expected to enhance the performance of individuals from the local population over those from other populations and thus reinforces the evolutionary value of natal homing (Quinn and Dittman 1990). Homing is therefore an important behavior for maintaining the genetic diver-

\footnotetext{
* Corresponding author: dimitry.gorsky@maine.edu

${ }^{1}$ Present address: Department of Wildlife Ecology, University of Maine, 5755 Nutting Hall, Orono, Maine 04469, USA
}

Received April 1, 2008; accepted February 23, 2009 Published online June 29, 2009 sity of salmon metapopulations while retaining local adaptations at smaller scales and promoting successful completion of an individual's life history.

Straying, or the return of adult salmon to areas other than the natal stream, can be considered either an alternate strategy to homing or simply a failure to home effectively. Straying may actually slow the process of local adaptation in tributaries while allowing new habitat to be used and poor habitat to be abandoned (Quinn 1993). When it occurs, this alternative behavior may be beneficial to the overall persistence of a metapopulation by reducing inbreeding and introducing potentially useful genetic variation via gene flow among locally adapted populations. Straying may naturally occur at some modest rate, but imposing an artificially high or low rate of straying may begin to impede or become detrimental to genetic population subdivision and local genetic adaptation. Heggberget et al. (1988) suggested a metapopulation theory wherein straying and homing exist in a dynamic equilibrium, maintaining the "evolution of several stocks within a river system." 
Conservationists often take advantage of the ability of salmon to imprint and home as adults to restore extirpated and threatened populations. The state of Maine has several rivers that still produce wild runs of Atlantic salmon Salmo salar, although adult returns have declined precipitously for more than 30 years (Fay et al. 2006). The Penobscot River currently has the largest Atlantic salmon population in Maine and the United States (Fay et al. 2006). This population is supported by the stocking of 1-year-old hatchery smolts, young-of-the-year parr, and unfed fry. The majority of returning adults $(70-98 \%)$ are produced from stocked smolts. Hatchery-produced Atlantic salmon juveniles are reared under accelerated growth conditions and are then stocked as 1-year-old smolts into the main-stem Penobscot River or tributaries. This type of stocking aims to obviate juvenile mortality associated with the natural freshwater environment in an effort to increase the number of emigrating smolts and ultimately the number of adult returns.

The Penobscot River offers an excellent opportunity to test the influences that stocking practices may have on path choice in returning adult salmon. In this study, we evaluated the behavior of Atlantic salmon returning as adults from four smolt stocking locations in the Penobscot River system. The objective of this study was to investigate whether Atlantic salmon stocked in different reaches of the Penobscot River system behave similarly when faced with a path choice between a major tributary mouth and the upriver main-stem channel. We further consider how Atlantic salmon from different stocking locations may differ in their value to the restoration effort.

\section{Methods}

Study site.-The Penobscot River system is Maine's largest river system, with a watershed of approximately $22,000 \mathrm{~km}^{2}$ (Figure 1). The river system is completely within in the state of Maine. It is $563 \mathrm{~km}$ long and has a total fall of $488 \mathrm{~m}$ from its highest point, Penobscot Lake. The river widens into Penobscot Bay near the town of Bucksport and is tidal from the bottom of the lowermost dam (Veazie Dam) at river kilometer ( $\mathrm{rkm})$ 47.5 to where it empties into the Gulf of Maine.

The Penobscot River has several hydroelectric facilities along its main stem and tributaries. In this study, we focused on behavior of returning adult Atlantic salmon at two specific hydroelectric projects located in the towns of Howland and West Enfield. These two dams are positioned at a major river fork, and both represent the fourth dam in the migratory path of upstream-migrating Atlantic salmon (Figure 1). The Howland Dam is located at the mouth of the Piscataquis River, a major tributary to the Penobscot
River at rkm 100. The West Enfield Dam is located about $1 \mathrm{~km}$ upstream on the main-stem Penobscot River at $\mathrm{rkm}$ 101. These two dams serve as a division between the main-stem Penobscot River, the Piscataquis River, and the upper Penobscot River (Figure 1). The river fork is a natural feature that offers the opportunity to test the path choice of Atlantic salmon from different stocking locations in a natural "Y-maze" experimental scenario.

The Piscataquis River and upper Penobscot River segments are very different in size and hydrology. The upper Penobscot River section has a watershed area of approximately $12,320 \mathrm{~km}^{2}$ that includes the East and West branches of the Penobscot River and the Mattawamkeag River. The East Branch $\left(2,896 \mathrm{~km}^{2}\right)$ has very little hydrologic regulation, while the West Branch $\left(5,518 \mathrm{~km}^{2}\right)$ is highly regulated with several hydroelectric facilities. The East and West branches converge above a main-stem Penobscot River hydroelectric facility located $149 \mathrm{~km}$ from the mouth of the river. The Mattawamkeag River $\left(3,906 \mathrm{~km}^{2}\right)$, an essentially natural, free-flowing river, joins the Penobscot River upstream of the West Enfield Dam. The result of this complex water management is that the flow of the upper Penobscot River section through West Enfield is highly regulated; most notably, low flows are higher and more stable than would be expected for a free-flowing river because each storage and hydroelectric facility in this complex is required to maintain a minimum flow. Although there are hydroelectric facilities in the Piscataquis River, they operate according to "run-of-the-river" regimes, and low flow mimics natural river conditions. This system responds rapidly to precipitation and is a very low-flow system during summer months while having relatively large pulses in the spring associated with thawing and runoff. The flow from the Piscataquis River contributes about $4 \%$ of the main-stem Penobscot River flow during dry summer conditions to about $25 \%$ in highflow years, with a median contribution of $14 \%$ to the flow of the lower Penobscot River (Table 1). The majority of flow in the lower Penobscot River is contributed from the upper Penobscot River watershed throughout the year, with low input from the Piscataquis River.

Smolt stocking.-Fish stocked in the Penobscot River system were 1-year-old Atlantic salmon smolts reared at the Green Lake National Fish Hatchery in Ellsworth, Maine. There were four major smolt stocking locations (Figure 1). The Howland site is located lowest in the system, approximately $1 \mathrm{~km}$ below the confluence of the Piscataquis River with the Penobscot River. This location is approximately at rkm 99. The West Enfield stocking site is located upstream 


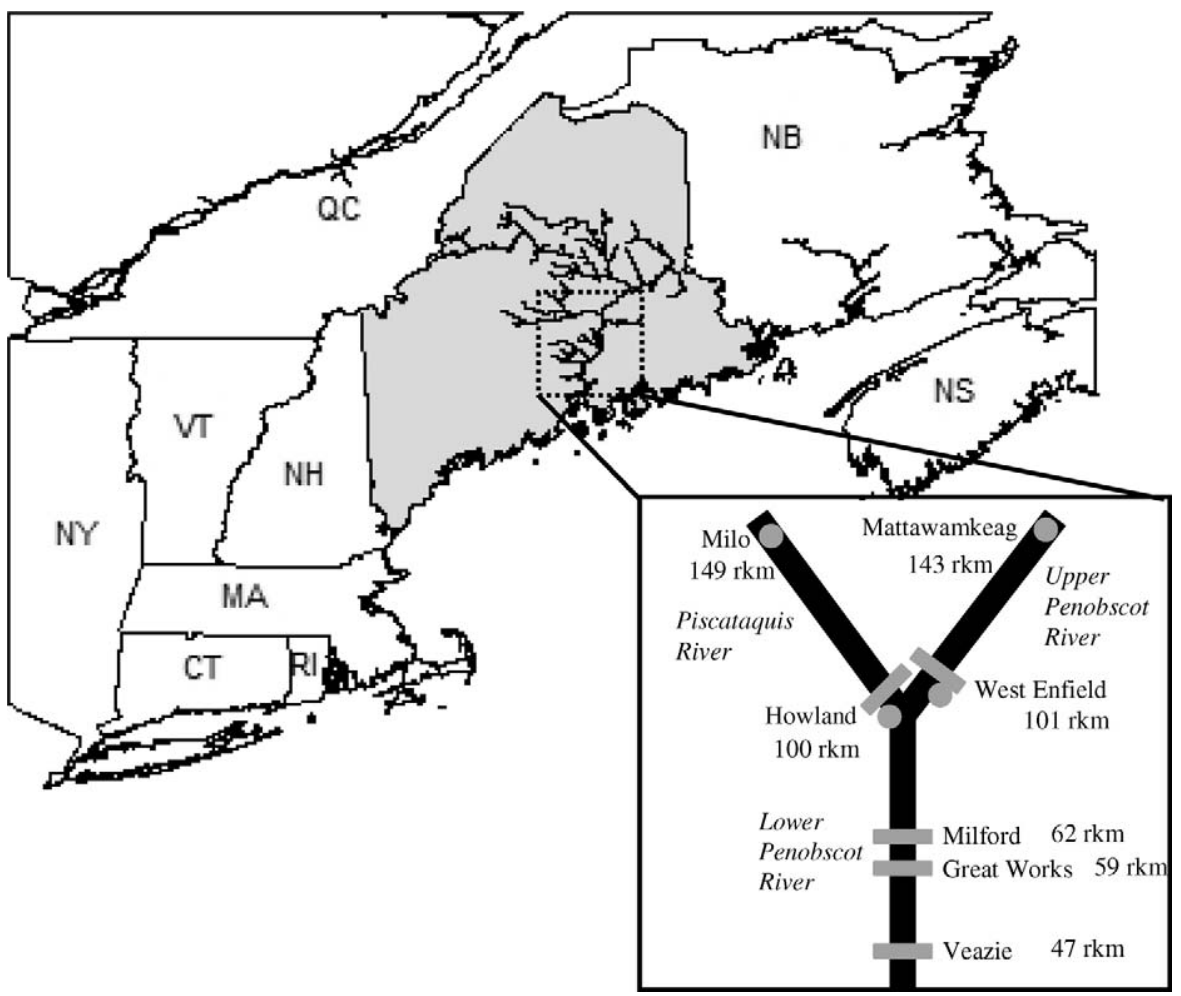

Figure 1.-The Penobscot River, Maine, watershed and surrounding states and territories. Inset shows a simplified schematic of the lower Penobscot River, depicting hydroelectric facilities (gray rectangles) and Atlantic salmon smolt stocking locations (gray circles; with associated river kilometer [rkm]). Names of river sections are in italics.

along the main-stem Penobscot River at rkm 101. This location is about $1 \mathrm{~km}$ upstream from the aforementioned confluence. The Milo stocking location is located up the Piscataquis River tributary at rkm 143. This location is approximately $43 \mathrm{~km}$ upstream of the river fork. Finally, the Mattawamkeag stocking location is near the confluence of the Mattawamkeag River with the Penobscot River at rkm 144 (43 km upstream of the river fork).

Three of the four locations (Milo, Howland, and

TABLE 1.- Relative percentage of mean monthly flow contributed by the Piscataquis River, Maine, to the Penobscot River (data from U.S. Geological Survey gages 01034000 , 01034500, and 01036390) for 2002-2004.

\begin{tabular}{lccc}
\hline Month & 2002 & 2003 & 2004 \\
\hline May & 18 & 18 & 18 \\
Jun & 18 & 20 & 13 \\
Jul & 11 & 14 & 15 \\
Aug & 4 & 11 & 20 \\
Sep & 4 & 9 & 13 \\
Oct & 10 & 25 & 14 \\
Nov & 12 & 22 & 21 \\
\hline
\end{tabular}

Mattawamkeag) were stocked using smolts trucked from the Green Lake National Fish Hatchery to release sites at the edge of the river. Stocking at these sites occurred on two distinct release dates each year, one in early to mid-April (early release) and the other generally 2 weeks later (late release). Stocking at the fourth site (West Enfield) was into a smolt holding facility, allowing for fish acclimation to river water followed by release into the river. Dates from all releases were transformed into standard weeks for cross-year comparison (Table 2). Considering week 1 of the calendar year to be January 1-7, stocking weeks ranged from week 15 for the earlier stocking event to week 22 for the later stocking event. Smolts released from the smolt ponds were released on week 18 in all but 1 year, when release was at the start of week 19. In general, the time between early and late releases was less than 3 weeks.

Returning adults used in this study were marked as smolts in 2000-2004 using fluorescent visual implant elastomer (VIE) tags (Northwest Marine Technology). The VIE tags consist of a liquid polymer material, which is injected into the adipose tissue surrounding 
TABLE 2.-Standard week (month and day in parentheses) for each smolt stocking event that produced adult Atlantic salmon used in a study of migratory path choice in the Penobscot River, Maine, 2002-2004. Standard weeks are based on January 1-7 as week 1.

\begin{tabular}{lcccc}
\hline Stocking location & 2000 & 2001 & 2002 & 2003 \\
\hline Howland & $15($ Apr 12) & 17 (Apr 25) & 17 (Apr 25) & $16($ Apr 16) \\
\multirow{2}{*}{ Milo } & 19 (May 9) & 19 (May 10) & 19 (May 10) & 18 (Apr 30) \\
\multirow{2}{*}{ Mattawamkeag } & 15 (Apr 11) & 17 (Apr 27) & 16 (Apr 16) & 16 (Apr 17) \\
\multirow{2}{*}{ West Enfield } & 19 (May 8) & 19 (May 11) & 19 (May 7) & 18 (May 1) \\
& 15 (May 10) & 17 (Apr 26) & 15 (Apr 15) & 16 (Apr 18) \\
\hline
\end{tabular}

the eyes of the fish. Different colors in combination with the right or left eye were used to uniquely mark fish, allowing the identification of the stocking year, stocking site, and release date for each tagged fish. Approximately 50,000 smolts were tagged for each of the stocking locations except West Enfield, which received about 25,000 smolts/year. Detection efficiencies of VIE tags were evaluated post hoc. Returning adults captured at the Veazie Dam fishway were examined for VIE tags and recorded upon capture at the trap. Some fish were taken as broodstock to the hatchery. At time of spawning, these fish were anesthetized, which allowed VIE tag location and color to be more definitively observed. Efficiencies were based on the ability to correctly identify the location and color of tags on fish at the trap versus the results from fish examined at the hatchery. The first 2 years of this study had the lowest efficiencies. The lowest efficiencies were also associated with the orange VIE color, which was often mistaken as yellow. In our study, the misidentification simply resulted in a difference in the stocking date of the fish and not the stocking location.

Experimental fish.-From 2002 to 2004, adult Atlantic salmon were captured and passive integrated transponder (PIT) tagged at the Maine Atlantic Salmon Commission's trapping facility, located at the upstream exit of the Veazie Dam fishway. This trapping facility was monitored for captured Atlantic salmon once or twice daily during May through late October of each year. Fish were captured at the trap and examined for adipose fin clips and VIE tags. Each adult Atlantic salmon's stocking date and location were identified by the color and location (right or left adipose tissue surrounding the eye) of the VIE mark. A 23-mm TIRIS Model RI-TRP-WR2B-03 read/write PIT tag (Texas Instruments, Dallas, Texas) was inserted into the dorsal musculature of each fish with a modified syringe tipped with a 12-gauge needle, and after recovery the fish was released into the river.

Tracking.-Adult Atlantic salmon migration was monitored throughout the Penobscot River using PIT technology, which is used frequently in fisheries management and behavioral research (Castro-Santos et al. 1996; Zydlewski et al. 2001; Aarestrup et al. 2003; Matter and Sandford 2003). The PIT tags are small (8-32 $\mathrm{mm}$ long) and inexpensive, have a long life (no battery), and can be programmed with unique identification codes to distinguish individual fish. This technology requires that the PIT tag pass near or through an antenna of a limited size $\left(<1 \mathrm{~m}^{2}\right)$ to transfer data and can be used to observe fine-scale movements as well as large-system movements of animals, depending on the placement of antennae.

On the Penobscot River, we placed PIT tag antennae in the fishway entrance and exit of each hydroelectric dam. The location of each antenna in the entrance and exit of the fishways then acted as a checkpoint for the tagged, migrating Atlantic salmon. Antennae were constructed of household 12-gauge electrical wire (thermoplastic, high-heat resistant, nylon coated) coiled through 1.3-cm-diameter polyvinyl chloride piping. Typical dimensions of the antennae in our fishways were less than $1 \mathrm{~m}^{2}$. Texas Instruments TIRIS Series 2000 readers were connected to the antennae by a twinaxial cable (for details see Castro-Santos et al. 1996) and were powered by $12-\mathrm{V}$ DC. A module unit located on the reader energized the antenna to create an electromagnetic field, which then energized any tag located in the field. Energized tags in turn emitted a unique code that was read by the reader and sent to a data logger with a date-time stamp. Data from antennae were logged on a Jornada 540 Pocket PC (Hewlett-Packard) using custom software provided by the S.O. Conte Anadromous Fish Laboratory, Turners Falls, Massachusetts (U.S. Geological Survey, Biological Resources Division [USGS-BRD]). Similar systems were used by Castro-Santos et al. (1996) and Zydlewski et al. (2001).

The PIT detection systems were routinely tested upon arrival at a site prior to downloading data and rebooting system components. Testing of each system consisted of sending a test tag with a known identification number directly through the center of 
each antenna. We were able to evaluate the range by listening for sounds emitted from a speaker connected to the reader unit. These beeps identified individual detections. During installation of our detection arrays, we often tuned down the antenna to give us a solid detection field with a detection range within $0.3 \mathrm{~m}$ of the antenna. The data file was then scanned to determine if the tag had been detected. Detection systems consistently logged the test tags while power was provided. Some instances occurred when power outages and vandalism caused system malfunction, but these were limited to a few cases. Antenna efficiencies were assessed by site based on the number of fish that were undetected at the entrance but were detected at the upstream exit antenna. The antennae within a fishway behaved very similarly, so this efficiency was used for both antennae. The efficiencies ranged from $78 \%$ (due to vandalism) to $100 \%$. The mean efficiency was $94 \%$. The low efficiency that was due to vandalism lasted for only a brief time period (approximately $10 \mathrm{~d}$ ) during 1 year while a new array was set up.

Data analysis.-We observed individual fish behavior in relation to the major fork in the river where the Piscataquis River joins the Penobscot River. Migratory path choice of fish from the four stocking locations was assessed based on PIT detections of individuals as they entered the Piscataquis River or upper Penobscot River sections by passing either the Howland Dam fishway or West Enfield Dam fishway, respectively. For the purpose of this study, we compared the behaviors of adult salmon returning from smolt stockings among the four stocking locations.

To test whether one stocking location or stocking week influenced the ability of Atlantic salmon to reach a study section, we compared the total number of tagged and released adults (from each stocking location and stocking week) that never reached Howland Dam or West Enfield Dam. These fish were not detected at any antennae located at either of these two dams and were assumed to have not arrived at the river fork. The comparison was done using a logistic regression model with arrival at either dam (yes or no) being the binomial response variable and stocking location or stocking week as the explanatory variable. Using the likelihood ratio test statistic of goodness of fit, logistic regressions were considered to be significant and a good fit if the likelihood ratio $P$-value was less than 0.05 (R Development Core Team 2005). This analysis tested the null hypothesis that stocking practices have no impact on the number of fish reaching the study site. This is important in identifying that our study fish provide an unbiased representation of the population.

Using the theory of homing in salmonids, we hypothesized that each Atlantic salmon would ap- proach and ascend the fishway that led towards the watershed in which they were stocked and likely imprinted. To analyze Atlantic salmon behavior in our study section, we compared returning adults to determine whether stocking practices, such as stocking location and stocking week, had any effect on three behavioral criteria we considered to be related to the path choice of imprinted adults. The three behavioral criteria we analyzed were (1) which fishway each individual approached first, (2) which fishway each individual first exited via the upstream end of the fishway, and (3) which fishway an individual was last known to have passed through. These criteria address the area to which each fish was initially attracted and the location of each fish prior to spawning. Each criterion was analyzed separately using logistic regression, with river choice being the dependent variable and stocking location or stocking week being the explanatory variable. These analyses tested the null hypothesis that stocking practices have no impact on path choice of returning adult Atlantic salmon.

The final analysis we performed evaluated fish behavior based on the number of attempts each adult made to enter each fishway before first passage. An entrance attempt was defined by a period of time where a group of the detections occurred in series without a 30-min gap between any two consecutive detections. Once there was a 30-min gap between detections, the current detections were considered a new attempt. We hypothesized that homing Atlantic salmon may perform searching behaviors while trying to locate specific olfactory cues and that the number of attempts could speak to the animal's ability to navigate efficiently towards imprinted olfactory cues. We compared the behavior of fish from the four stocking locations to see if individuals from any given stocking location were more likely to attempt a single entrance several times or to move back and forth between the two fishways. Using analysis of variance (ANOVA) with Tukey's post hoc multiple comparison (honestly significant difference) test, we compared the overall number of attempts (response variable) and the number of attempts made at either entrance (explanatory variable). This analysis tested the null hypothesis that stocking location has no influence on the number of fishway entrance attempts made at the river fork.

\section{Results \\ Atlantic Salmon Returns from Smolt Stockings and Tagging}

Over the span of this project, 663 adult Atlantic salmon were captured and observed with VIE tags at the Veazie Dam trapping facility (Table 3). Of these 663 adults, approximately $62 \%$ were tagged with a PIT 
TABLE 3.-Numbers of adult Atlantic salmon returning to the Veazie Dam trapping facility on the Penobscot River, Maine, by year and by identified stocking locations. The numbers of individuals that were tagged with passive integrated transponders and released are given under the "tagged" column; percentages of returning fish tagged and released are shown in the "\% tagged" column.

\begin{tabular}{lcrrc}
\hline Stocking location & Year & Returned & Tagged & $\%$ tagged \\
\hline Howland & 2002 & 58 & 39 & 67 \\
Mattawamkeag & & 38 & 20 & 53 \\
Milo & 42 & 26 & 62 \\
West Enfield & & 17 & 12 & 71 \\
All locations & & 155 & 97 & 63 \\
Howland & 2003 & 97 & 48 & 49 \\
Mattawamkeag & & 52 & 29 & 56 \\
Milo & & 45 & 26 & 58 \\
West Enfield & & 42 & 23 & 55 \\
All locations & & 236 & 126 & 53 \\
Howland & 94 & 63 & 67 \\
Mattawamkeag & & 43 & 27 & 63 \\
Milo & & 101 & 76 & 75 \\
West Enfield & & 34 & 23 & 68 \\
All locations & & 272 & 189 & 69 \\
& & & \\
Howland & All years & 249 & 150 & 60 \\
Mattawamkeag & & 133 & 76 & 57 \\
Milo & 188 & 128 & 68 \\
West Enfield & & 93 & 58 & 62 \\
All locations & & 663 & 412 & 62 \\
\hline
\end{tabular}

tag and released for observation of upstream migration behaviors. Within each of the 3 years of this study, a representative percentage of returning fish from each location was tagged and released. This study does not attempt to analyze the number of adults returning from each stocking location in relation to smolts stocked. This analysis may be forthcoming, and the associated data are proprietary at the time of writing.

\section{Detection of Atlantic Salmon Reaching either Howland Dam or West Enfield Dam Fishway Entrances}

We found no significant differences in the numbers of adult Atlantic salmon reaching the river fork among fish from each of the four stocking locations $\left(G^{2}=\right.$ $6.823, \mathrm{df}=3, P=0.078$ ). Approximately $69 \%$ of fish tagged and released were detected at the study site

TABLE 4.-Number of tagged adult Atlantic salmon that were released and detected as reaching the Penobscot River fork, Maine, and associated percentages of fish that reached the fork.

\begin{tabular}{lccc}
\hline $\begin{array}{c}\text { Stocking } \\
\text { location }\end{array}$ & $\begin{array}{c}\text { Number of } \\
\text { tagged adults } \\
\text { released }\end{array}$ & $\begin{array}{c}\text { Number of } \\
\text { tagged adults } \\
\text { arriving at fork }\end{array}$ & $\begin{array}{c}\text { Percent of } \\
\text { released fish } \\
\text { reaching the fork }\end{array}$ \\
\hline Howland & 150 & 103 & 69 \\
Mattawamkeag & 76 & 48 & 63 \\
Milo & 128 & 99 & 77 \\
West Enfield & 58 & 36 & 62 \\
All locations & 412 & 286 & 69 \\
\hline
\end{tabular}

(Table 4). The values for individual stocking locations ranged from $62 \%$ (West Enfield) to $77 \%$ (Milo). Standard week of smolt stocking had no significant effect on the ability of adults representing the four stocking locations to arrive at the river fork $\left(G^{2}=\right.$ 0.153 , $\mathrm{df}=1, P=0.696$ ). Based on results of these two logistic regressions, we did not reject the null hypothesis that stocking practices had no impact on the ability of fish to reach our study site. This suggests that failure of fish to reach the study site was not caused by stocking practices and was instead influenced by factors not evaluated in this study.

\section{Passage Behavior at the River Fork}

Analysis of Atlantic salmon returning from the four smolt stocking locations revealed that the fishway approached first by the adults was significantly related to where they were stocked as smolts $\left(G^{2}=125.988\right.$, df $=3, P<0.000$ ). Adults returning from the Howland and Milo stocking locations were observed to initially arrive at the Howland Dam fishway (leading to the Piscataquis River) disproportionately more often than West Enfield- or Mattawamkeag-stocked Atlantic salmon (Figure 2). Fifty-nine percent of the 103 Howland-stocked fish and $80 \%$ of the 99 Milo-stocked fish arrived at the Howland Dam first (Figure 2). In contrast, $97 \%$ of the 36 West Enfield-stocked fish and $93 \%$ of the 48 Mattawamkeag-stocked fish arrived at West Enfield Dam first. These results were consistent for both the first and last dam passage events exhibited by Atlantic salmon. The same path choice was observed for these two additional criteria (Figure 2).

The logistic regression of stocking week and location of first arrival showed a significant effect $\left(G^{2}=11.36\right.$, df $\left.=1, P=0.001\right)$. Upon further investigation, release week only played a significant role in determining path choice for the Atlantic salmon stocked at Howland $\left(G^{2}=6.049, \mathrm{df}=1, P=0.014\right.$; all other $P>0.05)$. The logistic regression for Howlandstocked fish suggested that the later they were stocked, the more likely they were to arrive at the West Enfield Dam fishway first. This was the only significant timeof-release effect observed for all four stocking locations.

Upon reaching the river fork, Atlantic salmon returning from each of the four stocking locations had significantly different numbers of entrance attempts (ANOVA: $F=5.249$, $\mathrm{df}=3, P=0.002$ ). Returning adults from Howland and West Enfield stocking locations had significantly more total attempts at fishway entrances prior to first passage than the returning adults from the tributary stocking sites at Milo and Mattawamkeag (Figure 3). These attempts are considered to be related to identifying an individual's 


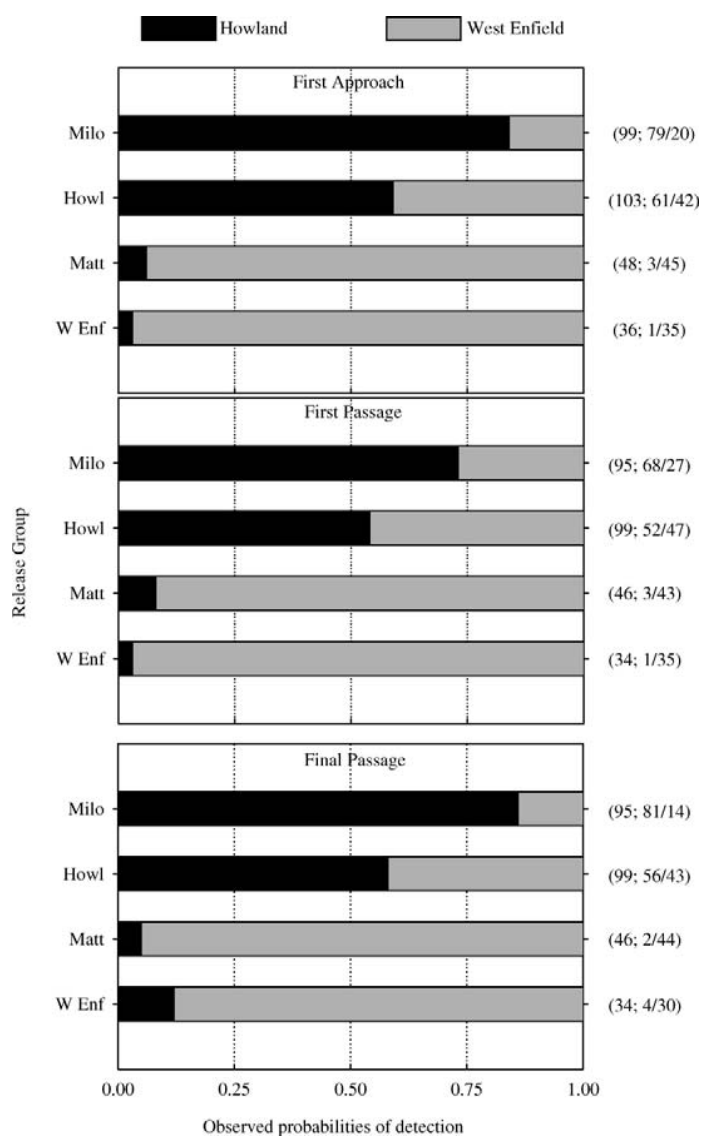

FIGURE 2.-Observed probabilities of Atlantic salmon from each Penobscot River, Maine, stocking site (Milo, Howland [Howl], Mattawamkeag [Matt], and West Enfield [W Enf]) being detected as returning adults during first approach, first passage, and final passage at either Howland Dam (black) or West Enfield Dam (gray) fishway. Total number of fish detected is shown in parentheses (followed by number detected at Howland Dam/number detected at West Enfield Dam).

path choice. The number of attempts did not significantly differ between Howland- and West Enfieldstocked Atlantic salmon $(P=0.988)$. Likewise, attempts made by Milo- and Mattawamkeag-stocked fish were not significantly different $(P=0.915)$.

\section{Discussion}

Adults from each stocking location behaved in ways consistent with the theory of homing. Returning adult Atlantic salmon originating from hatchery smolt stockings migrated towards the river sections or subwatersheds in which they were stocked. Withinriver and small-scale homing has been documented for Atlantic salmon (Heggberget et al. 1988) and sockeye salmon Oncorhynchus nerka (Quinn et al. 1999). In

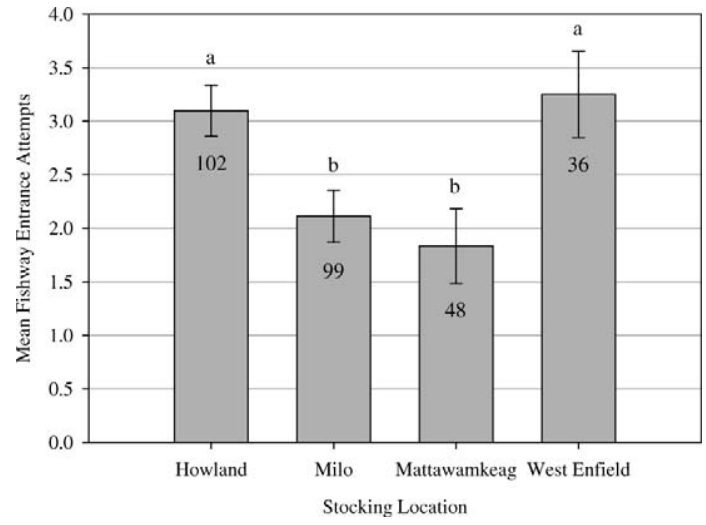

FIGURE 3.- Mean ( \pm SE) number of fishway entrance attempts made by passive integrated transponder tagged adult Atlantic salmon at either Howland Dam or West Enfield Dam (y-axis) based on smolt stocking locations ( $x$-axis) in the Penobscot River, Maine, from 2002 to 2004. Numbers represent sample sizes, and lowercase letters represent significant differences $(P<0.05)$ between stocking locations.

this study, Atlantic salmon from the upper Penobscot River stocking locations had higher observed percentages than those from the Piscataquis River stocking locations for choosing the path leading towards their respective watersheds. This may suggest that the stocking effect on path choice is stronger for upper Penobscot River stocking locations than for Piscataquis River stocking locations. Conversely, the lower observed percentages of Piscataquis River-stocked fish choosing the Howland Dam fishway may be due to the fact that imprinting can be overridden by physical factors, such as flow conditions and attraction to the fishway entrance. Although this research did not have sufficient data to examine the effect of river flow from the Piscataquis River on path choice, unsuccessful homing has often been attributed to differences in flow between imprinted streams and the opposite stream choice (Quinn et al. 1991; Unwin and Quinn 1993). Furthermore, failure to home to a natal river increased when the alternate path choice had higher flow. The section of Penobscot River watershed used in this study has a tributary with lower flows, representing the path choice of the Piscataquis River, and a higher-flow path choice leading to the upper Penobscot River. If river flow indeed has a significant effect on path choice, we would assume from previous research that Atlantic salmon stocked at Howland and Milo would be more likely to choose the wrong path than vice versa.

Along with the directional path choice, we were able to observe the decision-making process of fish from the four stocking locations with regard to how many attempts were made at the two dams. Atlantic salmon 
stocked higher up in a subwatershed chose a migratory path more efficiently when faced with a major fork in the river than those stocked lower in the system. Specifically, Milo- and Mattawamkeag-stocked fish made fewer total attempts to enter the fishways leading to each subwatershed and more efficiently chose to ascend the fishway leading toward each group's stocking location. Fish from the lower stocking locations made more attempts to enter the subwatershed than fish from the tributary stocking locations. The indecisive behavior of the Howland stocking group can be attributed to the stocking location being nonspecific to either river section even though it is closest to the Piscataquis River mouth ( $1 \mathrm{~km}$ below the confluence). These fish could be exposed to a mixture of both waters during imprinting. These results can be important to the survival and success of individual Atlantic salmon. The energetic and physical costs associated with passage delays may cause overripening of eggs, increased chance of egg retention, and reduced egg viability, all of which reduce spawning success (De Gaudemar and Beall 1998).

The timing of smolt release within standard weeks 15-22 had no effect on path choice for three of the four locations. The only stocking location with a significant temporal effect was Howland. This observed stocking week effect can be attributed to error associated with VIE tag detection. As described in Methods, there was an identified deficiency in evaluating the color of some tags. Tags that were identified as yellow during preliminary capture tended to actually be orange VIE tags $(50 \%$ in $2002 ; 15 \%$ in 2003). Assigning a fish to the left eye-yellow VIE group would represent the late stocking of Howland fish for 2002 and 2003 returns; some of these yellow tags were presumably misidentified orange tags. The misidentification of orange tags as yellow would result in more tags being assigned to the Howland late-release group fish than to the Howland early release group. If we had been able to reassign the fish misidentified as belonging to the Howland late-release group back to the Howland early release group, the statistical anomaly that we observed could easily have been negated. We believe that since no other stocking group displayed a time-of-stocking effect, this result for Howland-stocked fish can indeed be attributed to tag detection error.

Adult Atlantic salmon from all stocking locations were equally able to reach the two focal dams in the study. Although the $P$-value of 0.07 is not strictly significant, one may be tempted to infer some level of difference in ability to reach the study section among fish from different stocking locations. Power analysis of this data suggests that we would need a sample size of at least twice as many fish to detect significant differences between our largest observed difference of $62 \%$ (West Enfield) and 77\% (Milo) (power $\beta=0.56$, $n_{1}$ [number of returning adults from West Enfield] $=58$, $n_{2}$ [number of returning adults from Milo] $=128$ ). Since no statistical difference was found among the Atlantic salmon from the four stocking locations in terms of the ability to reach the focal dams, it is assumed that failure to reach these dams is due to other factors not considered in this study. In the Penobscot River, passage problems exist during extreme environmental conditions (Gorsky 2005). To reach this part of the river, Atlantic salmon must pass three hydroelectric facilities. Environmental conditions, such as high temperature, may reduce the rate of movement through the system, and high or low flows may make it difficult for the fish to find the fishways, leading to a lower ability of the adults to reach certain sections of the river.

Smolt stocking has been a valuable tool for ensuring increased numbers of returning adults. On the Penobscot River from 1978 to 2004, smolt stocking accounted for an average of $91 \%$ of the adult returns each year, ranging from $71.4 \%$ (1991) to $99.7 \%$ (1979), while natural reproduction and fry stocking accounted for the remainder (USASAC 2005). While smolt stocking may assist in population recovery due to sheer numbers of fish, it has also been demonstrated here that stocking locations can be used as a tool to guide returning adults to priority habitats. Assuming a high level of path choice leading to productive habitat, as shown here, adult Atlantic salmon will be able to spawn in areas ideal for juvenile growth during freshwater life stages. In turn, this could lead to higher natural production output due to spawners using the best habitat available. Ultimately, genetic groups could be stocked separately in different watersheds, allowing for some within-river population structure. In time, any existing or new trait variation associated with local fitness and population productivity might then be passed on. A crude level of regional stock differentiation can then be preserved or promoted by collecting broodstock at the major divergence of river sections. Given the apparent homing precision to the sections used in this study, collection of separate stocks could be relatively accurate while allowing for some gene flow associated with straying, which may be natural. This achievable level of within-river population structure would be more natural than the panmictic structure promoted with the single-river broodstock program currently in place and could lead to a population structure similar to those found in lessdisturbed systems (Beacham and Dempson 1998; Garrant et al. 2000).

The success and value of smolt stocking to the restoration of Atlantic salmon in the Penobscot River 
depend on the ability of returning adults originating from hatchery stocking groups to complete their life cycle in the environment present in the Penobscot River. While this study has identified that stocking location can increase the value of smolt stocking as a tool, further investigation into the absolute success of returning adult Atlantic salmon must address passage success, in-river survival, and spawning success. Migratory delays, fallback, or unsuccessful passage associated with hydroelectric facilities can have high costs through direct mortality or the reduction of energy stores needed for spawning success. An understanding of these mechanisms and their effects on adult spawning migrations will be valuable to the restoration of Atlantic salmon.

\section{Acknowledgments}

This project was a cooperative effort supported through funding and technical input by the University of Maine; USGS-BRD; USGS Maine Cooperative Fish and Wildlife Research Unit; Maine Atlantic Salmon Commission; Penobscot Indian Nation; and U.S. Fish and Wildlife Service (Green Lake National Fish Hatchery). We acknowledge the Maine Atlantic Salmon Commission for providing adults, performing tagging procedures, and collecting data; National Oceanic and Atmospheric Administration Fisheries for tagging the smolts; Alex Haro and Ted CastroSantos of the USGS-BRD for technical support and analytical techniques pertaining to PIT technology; Ken Beland for database development and utilization; and Mike Kinnison for critical review of this paper. We also acknowledge the various dam owners who allowed us to access the fishways daily and provided invaluable assistance, including Pennsylvania Power and Light, Great Lakes Hydro America, Bangor Pacific Hydro Associates, Interface Fabrics of Guilford, the Town of Dover-Foxcroft, Moosehead Furniture, and Ridgewood Maine Hydro Partners. Mention of trade names does not constitute endorsement by the U.S. Government.

\section{References}

Aarestrup, K., M. C. Lucas, and J. A. Hansen. 2003. Efficiency of a nature-like bypass channel for sea trout (Salmo trutta) ascending a small Danish stream studies by PIT telemetry. Ecology of Freshwater Fish 12:160168.

Beacham, T. D., and J. B. Dempson. 1998. Population structure of Atlantic salmon from the Conne River, Newfoundland as determined from microsatellite DNA. Journal of Fish Biology 52:665-676.

Castro-Santos, T., A. Haro, and S. Walk. 1996. A passive integrated transponder (PIT) tag system for monitoring fishways. Fisheries Research 28:253-261.

De Gaudemar, B., and E. Beall. 1998. Effects of overripening on spawning behavior and reproductive success of
Atlantic salmon females spawning in a controlled flow channel. Journal of Fish Biology 53:434-446.

Fay, C., M. Bartron, S. Craig, A. Hecht, J. Pruden, R. Saunders, T. Sheehan, and J. Trial. 2006. Status review for anadromous Atlantic salmon (Salmo salar) in the United States. Report to the National Marine Fisheries Service, U.S. Fish and Wildlife Service.

Garrant, D., J. J. Dodson, and L. Bernatchez. 2000. Ecological determinants and temporal stability of the within-river population structure in Atlantic salmon (Salmo salar L.). Molecular Ecology 9:615-628.

Gorsky, D. 2005. Site fidelity and the influence of environmental variables on migratory movements of adult Atlantic salmon (Salmo salar L.) in the Penobscot River basin, Maine. Master's thesis. University of Maine, Orono.

Heggberget, T. G., L. P. Hansen, and T. F. Naesje. 1988. Within-river spawning migration of Atlantic salmon (Salmo salar). Canadian Journal of Fisheries and Aquatic Sciences 45:1691-1698.

Matter, A. L., and B. P. Sandford. 2003. A comparison of migration rates of radio- and PIT-tagged adult Snake River Chinook salmon through the Columbia River hydropower system. North American Journal of Fisheries Management 23:967-973.

McDowall, B. M. 2001. Anadromy and homing: two lifehistory traits with adaptive synergies in salmonid fishes? Fish and Fisheries 2:78-85.

Quinn, T. P. 1993. A review of homing and straying of wild and hatchery-produced salmon. Fisheries Research 18:19-29.

Quinn, T. P., and A. H. Dittman. 1990. Pacific salmon migrations and homing: mechanisms and adaptive significance. Trends in Ecology and Evolution 5:174177.

Quinn, T. P., R. S. Nemeth, and D. O. McIsaac. 1991. Homing and straying patterns of fall Chinook salmon in the lower Columbia River. Transactions of the American Fisheries Society 120:150-156.

Quinn, T. P., E. C. Volk, and A. P. Hendry. 1999. Natural otolith microstructure patterns reveal precise homing to natal incubation sites by sockeye salmon (Oncorhynchus nerka). Canadian Journal of Zoology 77:766-775.

R Development Core Team. 2005. R: a language and environment for statistical computing. R Foundation for Statistical Computing, Vienna. Available: www. R-project.org.

Unwin, M. J., and T. P. Quinn. 1993. Homing and straying patterns of Chinook salmon (Oncorhynchus tshawytscha) from a New Zealand hatchery: spatial distribution of strays and effects of release date. Canadian Journal of Fisheries and Aquatic Sciences 50:1168-1175.

USASAC (U.S. Atlantic Salmon Assessment Committee). 2005. Annual report of the U.S. Atlantic Salmon Assessment Committee, Report Number 17: 2004 activities. USASAC Annual report 2005-17, Woods Hole, Massachusetts.

Zydlewski, G. B., A. Haro, K. G. Whalen, and S. D. McCormick. 2001. Performance of stationary and portable passive transponder detection systems for monitoring of fish movements. Journal of Fish Biology 58:1471-1475. 